This item was submitted to Loughborough's Research Repository by the author.

Items in Figshare are protected by copyright, with all rights reserved, unless otherwise indicated.

\title{
Space in the university library - an introduction
}

PLEASE CITE THE PUBLISHED VERSION

http://www.ashgate.com/isbn/9781409423829

PUBLISHER

() Ashgate Publishing

VERSION

VoR (Version of Record)

LICENCE

CC BY-NC-ND 4.0

REPOSITORY RECORD

Childs, Sarah, Graham Matthews, and Graham Walton. 2019. "Space in the University Library - an Introduction". figshare. https://hdl.handle.net/2134/11498. 
This item was submitted to Loughborough's Institutional Repository (https://dspace.lboro.ac.uk/) by the author and is made available under the following Creative Commons Licence conditions.

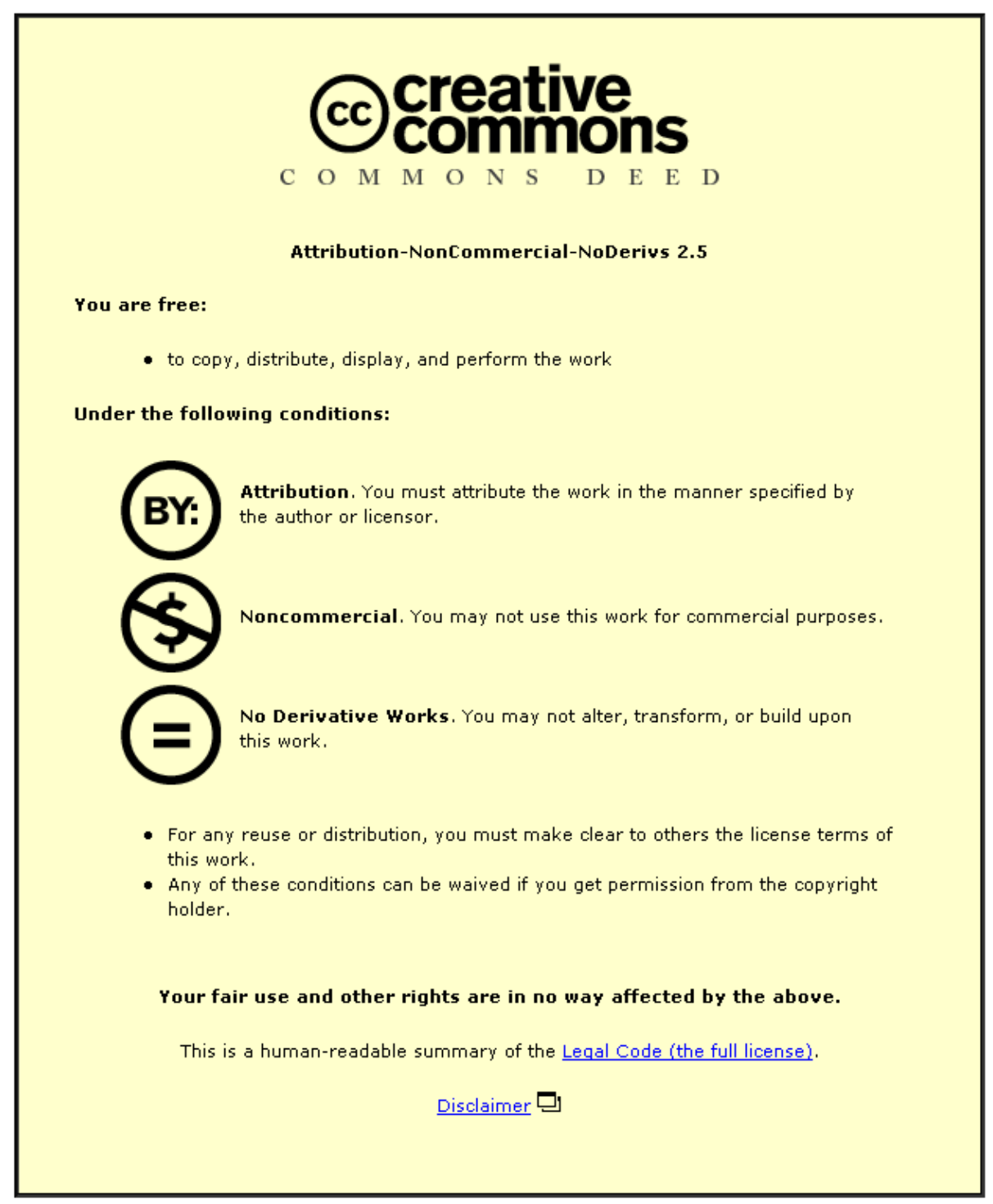

For the full text of this licence, please go to: http://creativecommons.org/licenses/by-nc-nd/2.5/ 


\title{
(C) Copyrighted Material \\ Chapter 1 \\ Space in the University Library - An Introduction
}

\author{
Sarah Childs, Graham Matthews and Graham Walton
}

\section{Introduction}

The university library has been described as being 'at the heart of the university' (Urquhart 1977: 2). In recent years, however, the purpose and very existence of the building itself has been questioned (Campbell 2006). A number of trends have influenced this discussion, including technological changes such as the growth in e-resources, the changing student population, developments in learning and teaching, and diminishing budgets. At the same time, there has been a great investment in university library space both before and since the millennium, with major projects in England such as, for example, Lanchester Library, the University of Coventry (Noon 2008), the Information Commons at the University of Sheffield (Lewis 2010), the David Wilson Library, and the University of Leicester (Fyfe 2010) attracting attention and awards. The same is happening elsewhere in the world as can be seen from chapters elsewhere in the book.

In the United Kingdom (UK) there has also recently been a number of public library closures due to the ongoing consequences of the credit crunch of 2008 (Lissaman 2011). University libraries will be affected too as major changes in UK Higher Education funding policy are likely to lead to the further tightening of budgets (Vasagar 2011). In other parts of the world, there may be similar financial issues or not, but questions about the importance of library space in a digital age are still pertinent. This changing landscape has prompted the idea for this book, which aims to capture the issues, opportunities, trends, and purposes that impact upon university library spaces across the world. Both editors have long-standing experience as academic library practitioners and users, and involvement in research in the academic library and information sector. They have both been involved in studies into academic library spaces (Walton 2006, Bryant et al. 2009).

Careful thought was given as to what the book should be and also what it should not be. Its intention was never to provide a collection of images, diagrams, or pictures of university library buildings past, present, and future. Those looking for this material are directed to the 'Designing Libraries' (2012) web site and the myriad of images on the Internet (see examples through 
references in chapters throughout this book). Its clear focus is to bring together the views and experiences of experts from across the world to highlight where university library physical space has come from and also where it is heading. Authors from Australia, Finland, Germany, UK, and USA consider a wide range of perspectives and opportunities which will help inform librarians from universities across the world as they develop their physical space. Senior managers in universities may find it informative to read the book to help them understand the issues and opportunities facing their institutions' libraries. Students of information and library science will also find the book helpful as it pulls together views and practical experience on the history and development of university libraries.

\section{Physical Library Space: The Shaping Trends Over the Years}

Physical space has not just become a key concern such that commentators try and predict its future role and place. Indeed, a book entitled The Library of the Future was written nearly 75 years ago that attempted to predict what libraries would look like (Headicar 1936). With this in mind, the authors determined to look back to see what predictions about university libraries and space have been made. When commentators have been predicting the future of university libraries they have varied substantially in the amount of attention devoted to the concept of space. The issues about physical space that writers and researchers discuss have changed a great deal over time; they are captured in Table 1.1 . 
Table 1.1 Trends in university library space

\begin{tabular}{|c|c|}
\hline Time & Trends in University Library Space \\
\hline Pre-1970s & $\begin{array}{ll}\text { - } & \text { Lack of space } \\
\text { - } & \text { Growing collections vs open access } \\
\text { - } & \text { Accommodating catalogue cards }\end{array}$ \\
\hline $1970 \mathrm{~s}$ & $\begin{array}{l}\text { - } \quad \text { Lack of space } \\
\text { - } \quad \text { Solutions to problems, e.g. microfiche, cooperation, deselection } \\
\text { - } \quad \text { Separate library space for undergraduates } \\
\text { - Changes in learning and teaching methods encourage increased use of } \\
\text { library space }\end{array}$ \\
\hline $1980 \mathrm{~s}$ & $\begin{array}{l}\text { New technology as overriding concern, e.g. microcomputers, } \\
\text { CD-ROMs } \\
\text { Staff space also needs to adapt }\end{array}$ \\
\hline $1990 \mathrm{~s}$ & $\begin{array}{l}\text { - } \quad \text { Technology calls into question need for physical library } \\
\text { - } \quad \text { Library as social space } \\
\text { - } \quad \text { Imanging pedagogy, e.g. group work } \\
\end{array}$ \\
\hline $2000 \mathrm{~s}$ & 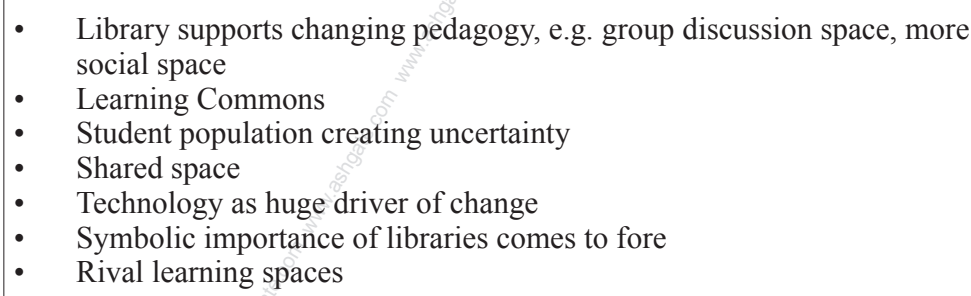 \\
\hline
\end{tabular}

Pre 1970s

(For details of the historical evolution of storage and study space in university libraries in the context of the development of universities, see Chapter 2.) For many university librarians in the UK and the USA in the early twentieth century, physical space was an issue of paramount importance. A common complaint in the literature is the idea of 'running out of space' (Rider 1944: 3 ). There are discussions of how to balance the ever-growing collections and the need for open access and space for scholars and students (Headicar 1936: 59); the idea of 'deselection' and weeding does not seem to be on the agenda. One of their major concerns for the future was how they would manage not only all their collections but the huge amount of space taken up by catalogue cards (Rider 1944). Authors from this period make the same kinds of prediction that occur right up to the present day, such as increased cooperation between different libraries (Rider 1944). Yet there 
are some novel and interesting predictions. For example, a book by Fremont Rider envisaged a future where catalogue cards are on microfiche, and the content of books is not in a separate location in the library, but is incorporated onto the selfsame catalogue card (Rider 1944). Whilst we may regard this today as a somewhat eccentric solution, it has relevance for contemporary accounts of the future. First, although this solution did not come to pass in its original form, are the e-resources we have in today's libraries so far away from this solution? However, as discussed in further detail below, these kinds of 'solution' have not succeeded in sating the demand for space. Secondly, it also demonstrates that technological developments have been viewed as a panacea in the past. Therefore, we should be cautious when considering the work of those writers who today see technological development as a means of reducing pressure on space in the future. (For a more detailed discussion on the concepts and theories relating to space in university libraries, see Chapter 3.)

$1970 s$

For those writing on the future of the university library in the 1970s, the concept of space does not appear to be of major importance. If physical space was considered at all, it was primarily the lack of it (Orne 1977, Urquhart 1977). Again, most authors were concerned that there would no longer be the space for their book and journal collections. Very little attention was paid to how library patrons might use this space in the future, apart from a discussion of polytechnic libraries which mentions the problem of lack of seating (Rogerson 1977: 46). However, whilst it did not come up as a major theme by those predicting the future of the library, the 'space factor' does appear to be of 'growing importance' for those dealing on the ground with university libraries (Teague 1979: 119). There was a growing recognition that something needed to be done to actively manage space, as demonstrated by Teague when he states "we are no longer able to envisage unending growth of great library buildings. Rather we look to planned stock revision and withdrawal, co-operative ventures in single copy depositories for groups of libraries and microform copies of all occasionally required volumes' (Teague 1979: 119). As we shall see, these solutions are still advocated today to solve the 'space problem'.

There are further common threads emerging which resonate today, including uncertainty about future funding (Orne 1977), although its impact on physical space could well have very different consequences. Another trend which has echoes today is the idea of having a separate library for undergraduate students, in response to the difficulty that undergraduate students had in navigating the expanding library collections (Braden 1970). This also apparently was the result of 'new teaching methods sending ... [the undergraduate] to the library with greater frequency' as, for example, 'independent reading was being encouraged' (Braden 1970: 1). This suggests that it is not true to say that learning and teaching methods 
remained static until the latter part of the twentieth century, where the effect of changes in learning and teaching methods is dwelt upon far more in the literature.

Already there is an understanding that technology will change the way library space is used, although clearly it is not understood just how much technology may change things (Smethurst 1977). For example, a book called Designing and Space Planning for Libraries from the period does not have a section devoted to technology, and the subject is mainly dealt with in terms of the amount of power that will be needed and the wires and cables (Cohen and Cohen 1979: 153). The idea of microfiche again comes up as a solution (Asleson 1978); practical experience of its use, however, has led to a certain caution in suggesting it as a cure-all for all space problems. It is suggested as a solution but is also perceived as having pitfalls, such as having to retain physical copies of all the items being microfiched (Asleson 1978).

$1980 \mathrm{~s}$

Compared to the 1970s, there is far less literature available on the future of libraries and library space from the 1980s. This may indicate a lack of discussion of the subject on the ground, and a lack of problems around space, although this is by no means certain. What is notable in the literature that is available is that there is far greater recognition of the way that technology may affect the library (Kapp 1987, Lucker 1987). A book published in 1987 recommends the provision of a computer room in libraries as 'a large majority of libraries and information centres can expect to be automated by $1995^{\circ}$ (Boss 1987: 104). Writers discuss a variety of different technologies coming in and impacting on library space in the present and the future - including microfiche, telefacsimiles, micro computers, CD-ROM workstations, and VCRs (Lucker 1987, Stahl 1987).

However, the themes from the 1970 s continue in that physical space is seen as an issue mainly in discussions around how libraries will accommodate the burgeoning technology in all its different formats (Kapp 1987, Stahl 1987). Cohen and Cohen acknowledge that 'the electronic revolution is beginning to have a major impact on library functions' (Cohen and Cohen 1981: 4). The way that students and staff use the space in a practical way for learning and research does not seem to be a focus, as it is overshadowed by the huge and varied technological change occurring at the time. Another new idea is a mention of how staff space is inadequate, particularly in light of technological development (Lucker 1987). Overall, there is a great deal of uncertainty as to how space will change in the future as the huge variety of technology being introduced means writers feel cautious about making bold predictions. Nevertheless, technology is the major discussion point in the literature, perhaps to the detriment of other issues which seem to have fallen by the wayside. 
The 1990s brought a greater awareness of the way that technological and other changes called into question the entire role of the physical library. Bloch and Hesse go as far as to say 'we lie at a threshold moment in the history of libraries' (Bloch and Hesse 1993: 1). There is now awareness that the library may disappear altogether, but most writers are unanimous in predicting a future for library buildings, albeit with a different purpose to that which the buildings served when they were writing (Lancaster 1993, Lucker 1993). Some writers discuss the impact of information being available online, though are dismissive of e-books (Line 1993, Raitt 1993). Predictions were starting to show an awareness of the ways that library users actually utilized space, even mentioning the social side of the library (Lucker 1993). The possible impact of new and future teaching methods, such as the increased use of group work, was also highlighted for the first time (Garrod 1999), as were wider issues in education, such as increased participation in higher education (Line 1993).

A key document of the 1990s which affected UK university libraries was the Follett Report (1993). This focused on the general situation for university libraries at a time of great change in the UK Higher Education sector, as polytechnics and colleges became universities. This included issues relating to physical space; for example, the way that space available in academic libraries had failed to keep pace with the huge increase in student numbers (Follett 1993). However, it was also important in that it made recommendations for the future to prevent this decline. As well as funding e-library projects, Follett also led to capital being spent on refurbishing and rebuilding libraries (Rusbridge 1998). This activity was a major contributor to the explosion in literature on library space in the twenty-first century.

\section{Onwards}

The literature on the future of academic libraries has seen a marked increase over the past ten years as trends from the 1990s have accelerated and brought the question of physical space in academic libraries of the future into even sharper relief. Current academic and professional discussion on the subject of future libraries tends to give much greater attention to the idea of space. For example, the Joint Information Systems Committee (JISC) Libraries of the Future Project devoted a whole section to the topic in the supplement they produced for The Guardian newspaper (JISC, 2008). The development and maintenance of a UK website on the subject of designing libraries illustrates the interest in physical library space, including in the university sector (Designing Libraries 2012). There is a split between those who see that a number of trends (explored in more depth in the following pages) means that the physical space of the library has increased in importance (McDonald 2010), and those who see libraries of the future as virtual rather than physical entities (Campbell 2006). There are those who focus on the universal and enduring appeal of the library as a learning space (Watson 2010), 
whilst others argue that the advent of digital information means we are operating in a totally new paradigm, and that space is now of low priority. Therefore, academic libraries should instead focus on more important aspects such as university-wide information management policies, and building strong relationships with faculties (Law 2009a). Whilst there does not seem to be a strong consensus on this debate, the fact that it is being debated at all demonstrates the increased importance of this issue in library and information science (see JISC 2009).

At the same time that the existence of the physical library is called into question, there is also a debate as to the purpose of the library. Whilst there is near universal consensus that academic libraries are about more than the physical collections which so preoccupied those writing in the mid twentieth century, the function of a modern university library is a hotly contested subject.

\section{Major Influencing Factors on University Library Space in 2012}

\section{Learning and Teaching Methods}

The role of physical space in the future of the library is being discussed a great deal more for a number of reasons. First, the idea of the library space as being increasingly social has gained popularity in recent years. In the United Kingdom, university library spaces such as the University of Sheffield's Information Commons, the University of Warwick's Learning Grid, and Glasgow Caledonian University's Saltire Centre (JISC 2012) have been built in a way that responds to current ideas around the idea of the library as a social space. The huge cost and effort of the redesign, rebuilding, and refurbishment involved in these projects also indicates a belief that things will continue in this direction (Caldwell 2006). This idea of a 'social' library reflects trends such as a change in learning and teaching methods (Caldwell 2006). These new ways of working mean that, for example, having a space where users have to sit in silence, not eating or using mobile phones, is difficult to sustain. For Gayton (2008), this has led to a social rather than communal use of space of which he is critical, but this trend shows little signs of abating in the future (McDonald 2010).

This is a change in physical space that seems to be driven by students, as feedback from students displayed on a number of university websites suggest a preoccupation with space (Queen Mary 2011, University of East Anglia 2011). For example, three out of seven of the suggestions in the 'You said, we did' section of the Queen Mary, University of London's library page directly relate to space issues. Space has also been a concern of library directors in recent years. For example, the SCONUL survey of 2008 revealed library space as the top concern of library directors (SCONUL 2008). Although space does seem to have declined as a concern in the survey (it had dropped to fifth place by 2010), this may well be because of other concerns, such as financial constraints, becoming more important, rather than space becoming less important (SCONUL 2010). Although these are 
current rather than future concerns, this feedback demonstrates that physical space is a major concern going forward for students and library managers alike.

\section{Changing Student Population}

The changing nature of the student population also has a possible impact, as distance learning, online classes and part-time studying become more common (Staley and Malenfant 2010). This potentially has rather alarming implications for physical library space as students from these backgrounds, it is assumed, will access the library remotely rather than physically. This is connected to budget cutbacks in higher education, where students may struggle to afford to study in more traditional ways (Bowcott 2011). However, it has also been noted that some of these non-traditional students may struggle with electronic library resources, as they may not have used them due to age (Munde and Marks 2009). Therefore, some of these students may use the physical library more regularly than a young undergraduate would. However, the recent 'Google Generation' report does seem to dispel the idea that technical skills and the ability to use digital information efficiently is connected to age (JISC 2007). Nevertheless, overall it is envisaged that the very different student populations at different universities - with factors such as age of students, or whether most students live on campus - could potentially create much greater differences in terms of the use of space in academic libraries.

\section{Technology}

However, perhaps the most dwelt-upon aspect of the future of academic library space is the role of technology, and the growing use of online resources. This is an extremely broad area, but debate mainly centres around remote access to resources, including the use of mobile technology, and the growing willingness and desire of students to access information electronically; hence the trend for library collections to be digital rather than physical (as physical material is digitized and newer 'born digital' material comes into the collection). Indeed, this trend has meant that the University of Strathclyde, Scotland, has recently decided to reduce the physical space that the library occupied (Law 2009b). The decision to do this stands in stark contrast to some of the changes made by the University of Sheffield, the University of Warwick, and Glasgow Caledonian University (amongst many others) discussed above. However, the staff at the University of Strathclyde felt the future users of their library would be 'digital natives' (Prensky 2001) who would prefer to access their information virtually. Therefore, with the option to study at home (off or on campus) and access library resources using a computer or mobile phone, why would there be a need for physical library space? Derek Law, the Chief Librarian at the University of Strathclyde, saw little point in fighting for a huge library space which would have fewer and fewer users (Law 2009b). 
A report by the Association of College and Research Libraries (ACRL), USA, that looks at how libraries will have changed by the year 2025, even discusses the possibility of pop-up campuses where libraries are purely virtual, as universities have no permanent physical home and simply hire out space when it is needed (Staley and Malenfant 2010). The development of technology, especially handheld devices for accessing information such as e-readers, is seen as a major contributing factor to this trend (Staley and Malenfant 2010). The Horizon Reports over the past six years have consistently predicted the increased use of mobile technology (Johnson et al. 2006, 2007, 2008, 2009, 2010, 2011). However, most librarians in the ACRL report also emphasized the continued need for a physical library, and the human face and other facilities that virtual services would not be able to offer. It is emphasized that whilst it may be the case that technology may change how students use the physical space of the library, it does not necessarily mean that they will no longer use the library at all.

\section{Alternative Learning Spaces and Campus Libraries}

Whilst technology may be seen as a major 'threat' to library services, a more literal physical threat is the development of alternative learning spaces, separate from the library, such as computer rooms and 'learning pods' (Oblinger 2006). The current use and future of these spaces appears to be unclear. Whilst some universities have just one central library, far more have several different libraries, perhaps at a variety of different locations and campuses. It seems to be the case that both in the UK and overseas there is a move to diminish the number of libraries run by the university, along with a trend to get rid of campuses and centralize universities in one location (Bevan 2006, Newman 2009).

\section{Shared Services}

Other future trends include the increased joint use of library space - this is a relatively new idea in the United Kingdom, but is far more prevalent in other parts of the world (McNicol 2008, Peterson 2005). The university library space may increasingly be shared with further education or community colleges, health libraries, or even public libraries. The first shared university/public library space in England is being built as a partnership between Worcestershire County Council and the University of Worcester, to be known as 'The Hive' (Worcestershire County Council 2012). This could become more and more common as budgets are squeezed in both public services and the higher education sector (Keene and Fairman 2011).

Related to this is the idea of university libraries also housing other services, which has been the case in public libraries for many years (Hoare 2008). For example, the University of Leicester Library, which was rebuilt and reopened in 2008, has other non-library facilities such as a Careers Centre within the library building (Jones 2008). Academic libraries in the UK over the past 20 years have 
already begun to incorporate related services, and many became converged services known as learning resources, or information services. Just as the move to more learning space is to a large degree student-led, it appears these converged and 'super-converged' services are a response to student demand (Appleton 2011: 86). It is also the case that they may be more cost-effective for universities than several separate and scattered student services (Appleton 2011: 87). These changes have typically involved accommodating computers into the space, but may indicate the beginnings of a new way of looking at libraries. The word 'library' seems to be back in vogue at the moment, but for many years libraries were under pressure to seek alternative names such as 'learning resource centres'. The idea being that a learning resource centre encapsulates the qualities of the future library far more than the term 'library' itself, which conjures up images of dusty shelves (Weise 2004, Choy 2011).

\section{Library as a Symbol}

These concerns over the name of libraries indicate a feeling amongst librarians and information professionals that libraries be perceived as more than the physical collections. If people are no longer using libraries to access the physical books, journals, and other resources, the perception of libraries as places of knowledge and learning, where students and staff can go to think and learn, becomes even more important. As many writers point out, the view of libraries as symbolic centres of learning, culture, and much more has a long history from ancient times (Weise 2004, Demas 2005). However, the library of the past, including university libraries themselves, perhaps cultivated an image of a space which was more like a museum for books, rather than a centre of learning (Manoff 2001). If the feedback from current students is that there is not enough space, this indicates that, however unconsciously, they view libraries as more than the sum of their collections. Therefore, whilst previous predictions viewed university libraries as ever-expanding book warehouses, the current trend is for them to be viewed increasingly as places people go to 'get serious' (Freeman 2005: 3), as it is somewhere they associate with serious study and thought.

\section{Overview of this Book}

An aspiration for this book is that after it has been read, the reader will understand how university library space has developed over centuries and have an insight into what is influencing the space in the second decade of the second millennium. The book also aims to give the reader an informed vision about where university library space will go to as the century progresses. In order to understand where university library buildings are going it is important to have an insight into where they have come from. Professor John Feather provides this overview in Chapter 2, which 
considers the history of university libraries and the space they have occupied. Over the years a variety of theories around physical space and university libraries have been aired, and these are explored by Eigenbrodt in Chapter 3. University libraries' physical space currently has to be adapted and designed to accommodate both digital and paper collections. Issues relating to the digital library are addressed by Holley in Chapter 4, and Jones considers printed collections in Chapter 5. University libraries have to support the learning as well as the research activities of their wider organization. In Chapter 10 Jamieson considers how the library can provide a learning space, and Hill and Ramaswamy in Chapter 11 give an overview of research space provision. New university library space can be developed and provided by building a new library, by refurbishing an existing library, or by sharing a building with other services. In Chapter 7, Cannell considers approaches to refurbishment; developing a new university library is addressed by Banks in Chapter 6, and Appleton in Chapter 8 looks at the approaches that can be taken in sharing space with other university service providers. There is a range of management issues and concerns around the university library in the digital age. An aspect which has attracted recent significance is the development of the green, eco-friendly university library building. Matthews in Chapter 13 outlines issues involved in this, with examples. Having an effective and efficient work force for the university library and providing them with appropriate physical space is crucial. Purcell explores the issues around making sure this takes place in Chapter 9. It is also imperative that library managers can provide evidence and evaluation into how the university library physical space is being used. Iivonen and colleagues provide an example of one approach as to how this can be achieved in Chapter 12. The final chapter, Chapter 14, by considering the views of those addressing the issues of space and its use in university libraries now, looks to the future to anticipate what might impact upon university libraries and their spaces.

\section{References}

Appleton, L. 2011. Super-convergence. Liverpool John Moores University. SCONUL Focus [Online], 51, 85-89. Available at: http://www.sconul.ac.uk/ publications/newsletter/51/27.pdf [accessed 01.09.2011].

Asleson, R.F. 1978. Microforms as an alternative to building, in: Running Out of Space: What are the Alternatives? Proceedings of the Preconference, San Francisco, June 1975, edited by G. Novak. Chicago: American Library Association, 24-31.

Bevan, N. 2006. Brunel University: Closure of Osterley Campus. SCONUL Focus [Online], 38, 126-127. Available at: http:/www.sconul.ac.uk/publications/ newsletter/38/37.pdf [accessed 20.08.2011].

Bloch, R.H. and Hesse, C. 1993. Future Libraries. Berkeley, CA: University of California Press. 
Boss, R.W. 1987. Information Technologies and Space Planning for Libraries and Information Centers. Boston, MA: G.K. Hall.

Bowcott, O. 2011. Open University may be in its 40s - but students are getting younger. The Guardian [Online], 3 January. Available at: http://www.guardian. co.uk/education/2011/jan/03/open-university-students-younger [accessed 21.04.2012].

Braden, I.A. 1970. The Undergraduate Library. Chicago, IL: American Library Association.

Bryant, J., Matthews, G., and Walton, G. 2009. Academic libraries and social and learning space: A case study of Loughborough University Library, UK. Journal of Librarianship and Information Science [online], 41(1), 7-18. Available at: http://lis.sagepub.com/content/41/1/7.short [accessed 10.02.2011].

Caldwell, T. 2006. Future shock. Information World Review, 225, 19-22.

Campbell, J.D. 2006. Changing a cultural icon: The academic library as a virtual destination. Educause Review [Online], 41(1), 16-30. Available at: http://net. educause.edu/ir/library/pdf/erm0610.pdf [accessed 07.02.2011].

Choy, F.C. 2011. From library stacks to library-in-a-pocket: Will users be around? Library Management [Online] 32(1/2), 62-72. Available at: http://www. emeraldinsight.com/journals.htm?articleid=1901414 [accessed 14.06.2011].

Cohen, A. and Cohen, E. 1979. Designing and Space Planning for Libraries: A Behavioral Guide. New York: Bowker.

Cohen, E. and Cohen, A. 1981. Automation, Space Management and Productivity: A Guide for Libraries. New York: Bowker.

Demas, S. 2005. From the ashes of Alexandria: What's happening in the college library? in Library as Place: Rethinking Roles, Rethinking Space. Washington, DC: Council on Library and Information Resources, 25-40. CLIR Publication No 129. Available at: http://www.clir.org/pubs/reports/pub129/pub129.pdf [accessed 18.04.2012].

Designing Libraries. Available at: http://www.designinglibraries.org.uk/ [accessed 20.04.12].

Follett, B. 1993. Joint Funding Council's Libraries Review Group: Report (The Follett Report). Available at: http:/www.ukoln.ac.uk/services/papers/follett/ report/ [accessed 10.06.2011].

Freeman, G. T. 2005. The library as place: Changes in learning patterns, collections, technology and use, in Library as Place: Rethinking Roles, Rethinking Space. Washington DC: Council on Library and Information Resources, 1-9. CLIR Publication No 129. Available at: www.clir.org/pubs/reports/pub129/pub129. pdf [accessed 18.04.2012].

Fyfe, C. 2010. David Wilson Library [University of Leicester, England], Fit for what purpose? Planning libraries for the users of the future, 15th Seminar of the LIBER Architecture Group, 12-16 April 2010, Madrid, Spain. Available at: http://147.88.230.242/liber-lag/lageps.htm\#madrid [accessed 19.04.12].

Garrod, P. 1999. Survival strategies in the learning age - hybrid staff and hybrid libraries. Aslib Proceedings [Online], 51(6), 187-194. Available at: 
http://www.emeraldinsight.com/journals.htm?articleid=863842 [accessed 05.02.2011].

Gayton, J.T. 2008. Academic libraries: 'social' or 'communal'? The nature and future of academic libraries. Journal of Academic Librarianship [Online], 34(1), 60-66. Available at: http://lis.sagepub.com/content/41/1/7.short [accessed 10.07.2012].

Headicar, B.M. 1936. The Library of the Future. London: Allen and Unwin.

Hoare, S. 2008. 'Buildings need to inspire'. EducationGuardian.co.uk [Online], 22 April. Available at: http://education.guardian.co.uk/librariesunleashed/ story/0,,2274826,00.html [accessed 20.04.2012].

Johnson, L.F. et al. 2006. 2006 Horizon Report. Austin TX: The New Media Consortium.

Johnson, L.F. et al. 2007. 2007 Horizon Report. Austin TX: The New Media Consortium.

Johnson, L.F. et al. 2008. 2008 Horizon Report. Austin: TX: The New Media Consortium.

Johnson, L.F. et al. 2009. 2009 Horizon Report. Austin, TX: The New Media Consortium.

Johnson, L.F. et al. 2010. 2010 Horizon Report. Austin, TX: The New Media Consortium.

Johnson, L.F. et al. 2011. 2011 Horizon Report. Austin, TX: The New Media Consortium. Available at: http://www.nmc.org/publications/horizon-report2011-higher-ed-edition [accessed 10.07.2012].

JISC. 2007. Information Behaviour of the Researcher of the Future. CIBER Briefing Paper 9. London: UCL. Available at: http://www.jisc.ac.uk/media/ documents/programmes/reppres/gg_final_keynote_11012008.pdf [accessed 08.08.2012].

JISC. 2008. Libraries unleashed. EducationGuardian.co.uk [Online], 22 April. Available at: http://education.guardian.co.uk/librariesunleashed [accessed 21.04.2012].

JISC. 2009. JISC Campaign: Libraries of the Future. Available at: http://www.jisc. ac.uk/media/documents/publications/lotfbrochure.pdf [accessed 20.04.12].

JISC. 2012. infoNet. Planning and Designing Technology-Rich Learning Spaces. Case Study. Glasgow Caledonian University, Saltire Centre. Available at: http://www.jiscinfonet.ac.uk/infokits/learning-space-design/more/casestudies/gcu [accessed 13.04.12].

Jones, L. 2008. David Wilson Library opens. SCONUL Focus [Online], 44, 8283. Available at: http://www.sconul.ac.uk/publications/newsletter/44/23.pdf [accessed 30.08.2011].

Kapp D. 1987. Designing academic libraries: Balancing constancy and change, in The Forgiving Building: A Library Building Consultants' Symposium on the Design, Construction and Remodelling of Libraries to Support a HighTech Future, edited by G. Novak et al. Library Hi Tech [Online], 5(4), 82- 
85. Available at: http://www.emeraldinsight.com/journals.htm?issn=0737$8831 \&$ volume $=5 \&$ issue $=4$ [accessed 07.02.2011].

Keene, J. and Fairman, R. 2011. Building an integrated work force through shared values: The Worcester Library and History Centre. Library Review [Online] 60(3), 188-201. Available at: http://www.emeraldinsight.com/journals. htm? volume $=60 \&$ issn $=0024-2535 \&$ issue $=3$ [accessed 07.01.2011].

Lancaster, F.W. 1993. Introduction: Threat versus opportunity, in Libraries and the Future: Essays on the Library in the Twenty-first Century, edited by F.W. Lancaster. New York: The Haworth Press, 1-4.

Law, D. 2009a. Academic digital libraries of the future: An environment scan. New Review of Academic Librarianship [Online], 15(1), 53-67. Available at: http://www.tandfonline.com/doi/abs/10.1080/13614530903069307 [accessed 10.02.2011].

Law, D., 2009b. An awfully big adventure: Strathclyde's digital library plan. Ariadne [Online], 58. Available at: http://www.ariadne.ac.uk/issue58/law/ [accessed 07.02.2011].

Lewis, M. 2010. The University of Sheffield Library Information Commons: A case study. Journal of Library Administration [Online], 50(2), 161-178. Available at: http://www.tandfonline.com/doi/pdf/10.1080/01930820903455040 [accessed 30.06.2011].

Line, M.B. 1993. Libraries and information services in 25 years' time: A British perspective, in Libraries and the Future: Essays on the Library in the Twenty-first Century, edited by F.W. Lancaster. New York: The Haworth Press, 73-84.

Lissaman, C. 2011. Library closure threats spark campaigns across England. $B B C$ News England [Online], 26 January. Available at: http://www.bbc.co.uk/news/ uk-england-12239388 [accessed 20.04.2012].

Lucker, J. 1987. Adapting libraries to current and future needs, in The Forgiving Building: A Library Building Consultants' Symposium on the Design, Construction and Remodelling of Libraries to Support a High-tech Future, edited by G. Novak et al. Library Hi Tech [Online], 5(4), 85-87. Available at: http:// www.emeraldinsight.com/journals.htm? issn $=0737-8831 \&$ volume $=5 \&$ issue $=4$ [accessed 07.02.2011].

Lucker, J. 1993. The library as place, in Research Libraries: Yesterday, Today and Tomorrow, edited by W.J. Welsh. Westport, CT: Greenwood, 3-17.

Manoff, M. 2001. The symbolic meaning of libraries in a digital age. Libraries and the Academy [Online], 1(4), 371-381. Available at: http://muse.jhu. edu/login?auth $=0 \&$ type $=$ summary\&url=/journals/portal_libraries_and_the academy/v001/1.4manoff.html [accessed 30.05.2011].

McDonald, A. 2010. Libraries as places: Challenges for the future, in Envisioning Future Academic Library Services: Initiatives, Ideas and Challenges, edited by S. McKnight. London: Facet, 31-54.

McNicol, S. 2008. Joint-use Libraries: Greater than the Sum of the Parts. Oxford: Chandos. 
Munde, G. and Marks, S. 2009. Surviving the Future: Academic Libraries, Quality and Assessment. Oxford: Chandos.

Newman, M. 2009. Cumbria plans to 'mothball' historic campus. Times Higher Education [Online], 5 December.Available at: http://www.timeshighereducation. co.uk/story.asp? storycode $=409424$ [accessed 20.04.2012].

Noon, P. 2008. The Lanchester Library: Building a sustainable library. 14th Seminar of The LIBER Architecture Group in Hungary: Budapest and Debrecen 8-12 April 2008. Available at: http://147.88.230.242/liber-lag/PP_ LAG_08/Wednesday/Noon_Budapest_08_def.pdf [accessed 19.04.2012].

Oblinger, D. 2006. Learning spaces. Educause. Available at: http://www.educause. edu/research-and-publications/books/learning-spaces [accessed 10.07.2012].

Orne, J. 1977. Library building trends and their meanings. Library Journal [Online], 102(21), 2397-2401. Available at: http://connection.ebscohost. com/c/articles/5713704/library-building-trends-their-meanings [accessed 10.07.2012].

Peterson, C.A. 2005. Space designed for lifelong learning: The Dr. Martin Luther King Jr. Joint-Use Library, in Library as Place: Rethinking Roles, Rethinking Space. Washington DC: Council on Library and Information Resources, 5665. CLIR Publication No 129. Available at: http://www.clir.org/pubs/reports/ pub129/pub129.pdf [accessed 18.04.2012].

Prensky, M. 2001. Digital Natives, Digital Immigrants. On the Horizon [Online], 9(5), 1-6. Available at: http://www.emeraldinsight.com/journals. htm? articleid=1532742 [accessed 02.02.2011].

Queen Mary, University of London, 2011. LibQUAL+${ }^{\circledR}$ at Queen Mary: Comments from the 2008 survey. Available at: http://www.library.qmul.ac.uk/ libqual2011/2008comments [accessed 20.06.2011].

Raitt, D. 1993. The library of the future, in Libraries and the Future: Essays on the Library in the Twenty-first Century, edited by F.W. Lancaster. New York: The Haworth Press, 61-72.

Rider, F. 1944. The Scholar and the Future of the Research Library. New York: Hadham.

Rogerson, I, 1977. Polytechnics and future collections, in The Future of Library Collections: Proceedings of a Seminar held by the Library Management Research Unit, University of Technology, Loughborough, 21-23 March 1977. Loughborough: Library Management Research Unit, 40-50.

Rusbridge, C. 1998. Towards the hybrid library. D-Lib Magazine [online], July/August 1998. Available at: http://dlib.ukoln.ac.uk/dlib/july98/ rusbridge/07rusbridge.html [accessed 10.06.2011].

SCONUL 2008. Top Concerns 2008. Available at: http://www.sconul.ac.uk/ members/topconcerns/report2008.pdf [accessed 10.06.2011].

SCONUL 2010. Top Concerns 2010. Available at: http://www.sconul.ac.uk/ members/topconcerns/report2010.pdf [accessed 10.06.2011].

Smethurst, J.M. 1977. A practical case study, in The Future of Library Collections: Proceedings of a Seminar held by the Library Management Research Unit, 
University of Technology, Loughborough, 21-23 March 1977. Loughborough: Library Management Research Unit, 22-31.

Stahl, W.M. 1987. General observations, in Drabenstott, J. et al., Designing Libraries for a High-Tech Future. Library Hi Tech [Online], 5(4), 104105. Available at: http://www.emeraldinsight.com/journals.htm?issn=07 $378831 \&$ volume $=5 \&$ issue $=4 \&$ articleid $=1676048 \&$ show $=$ html [accessed 07.02.2011].

Staley, D.J. and Malenfant, K. 2010. Futures thinking for academic librarians: Higher education in 2025. Association of College and Research Libraries. Available at: http://www.ala.org/acrl/sites/ala.org.acrl/files/content/issues/ value/futures2025.pdf [accessed 20.04.2012].

Teague, S.J., 1979. Microform Librarianship, 2nd edition. London: Butterworths.

University of Sheffield Information Commons. Available at: http://www.sheffield. ac.uk/infocommons [accessed 13.4.12].

University of Warwick Learning Grid. Available at: http://www2.warwick.ac.uk/ services/library/grid/ [accessed 13.4.12].

Urquhart, D.J., 1977. The Urquhart Report, in The Future of Library Collections: Proceedings of a Seminar held by the Library Management Research Unit, University of Technology, Loughborough, 21-23 March 1977. Loughborough: Library Management Research Unit, 1-9.

University of East Anglia, 2011. You said, we did. Available at: http://www.uea. ac.uk/is/yousaidwedid [accessed 20.06.2011].

Vasagar, J. 2011. University funding cuts: Which institutions are worst hit? The Guardian, 17 March. [Online] Available at: http://www.guardian.co.uk/news/ datablog/2011/mar/17/university-funding-cuts-institution-hefce-universities [accessed 21.04.2012].

Walton, G., 2006. Learners' demands and expectations for space in a university library: Outcomes from a survey at Loughborough University. New Review of Academic Librarianship [Online], 12(2), 133-149. Available at: http:// www.tandfonline.com/doi/abs/10.1080/13614530701330430 [accessed 20.08.2012].

Walton, G., 2009. Theory, research, and practice in library management 6 : Managing uncertainty through scenario planning. Library Management [Online], 30(4/5), 334-341. Available at: http://www.emeraldinsight.com/ journals.htm?articleid $=1789749 \&$ show $=\mathrm{html}$ [accessed 29.08.2011].

Watson, L., 2010. The future of the library as a place of learning: A personal perspective. New Review of Academic Librarianship [Online], 16(1), 45-56. Available at: http://www.tandfonline.com/doi/ abs/10.1080/13614530903574637 [accessed 30.08.2011].

Weise, F., 2004. Being there: The library as a place. Journal of the Medical Library Association [Online], 92(1), 6-13. Available at: http://www.ncbi.nlm.nih. gov/sites/entrez? $\mathrm{cmd}=$ Search\&db=pmc\&term $=1536-5050 \% 5$ Bjour $\% 5 \mathrm{D} \% 20$ AND $\% 202004 \% 5 B d p \% 5 D \% 20 A N D \% 2092 \% 5$ Bvolume $\% 5$ D $\% 20 A N D \% 20$ 1\%5Bissue $\% 5 \mathrm{D} \% 20$ AND $\% 206 \% 5$ Bpage $\% 5$ D [accessed 31.05.2011]. 


\section{(C) Copyrighted Material}

Worcestershire County Council. 2012. The New Worcester Library and History Centre. Available at: http://www.worcestershire.gov.uk/cms/records/the-newwlhc.aspx [accessed 21.04.2012]. 
